\title{
Long-term hydrological changes over a seventeen-year period in temporary ponds of the Doñana N. P. (SW Spain)
}

\author{
Laura Serrano *, Mari Paz Esquivias-Segura and María Zunzunegui \\ Dept. Plant Biology and Ecology, University of Sevilla. P.O. Box 1095. E-41080 Sevilla, Spain. Tel. +34 95 \\ 4557063 \\ * Corresponding author: serrano@us.es
}

Received: 27/9/07 Accepted: 12/11/07

\begin{abstract}
Long-term hydrological changes over a seventeen-year period in temporary ponds of the Doñana N. P. (SW Spain)

Hydrological changes of 6 temporary ponds in the Doñana National Park were monitored over 17 years (from $1^{\text {st }}$ October 1989 through $30^{\text {th }}$ September 2006) by recording the shallow water-table (in 1 to 8 week intervals) and the duration of pond wet phase (or hydroperiod) during each hydrological cycle. The annual average rainfall was $559 \mathrm{~mm}$ during the 17 years of the study, which included six wet, six moderate, and five dry cycles, all in a seemingly random sequence. The average wet period extended from October until the end of March, (both inclusive), while the dry season occupied the rest of the year. The water-table in the ponds oscillated each year following this alternation of rainy and dry seasons, but this oscillation was minimal during dry years, and even failed to occur at some ponds. Since 1998/99 onward, the average hydroperiod has shortened by three months in Charco del Toro pond, and by almost two months in El Brezo pond. On the other hand, the rest of the ponds studied, situated at more than $1 \mathrm{~km}$ from Matalascañas, barely exhibited a reduction in their hydroperiod. These results suggest that groundwater supply to these ponds ponds has been probably reduced by the pumping subterranean water to the Matalascañas tourist resort, whose pumping stations are located less than $1 \mathrm{~km}$ away from the two most affected ponds (Charco del Toro and Brezo). It is necessary for these pumping stations to be relocated at a greater distance to avoid any further impact to the ponds inside the Doñana Biological Reserve, and a specific management plan needs to be developed for those ponds. The monitoring of changes in the vegetation around the Doñana ponds can be a useful tool to detect even subtle hydrologic variations. Tamarix canariensis coverage has increased since established on the northern side of Taraje pond during the dry season of 1988/89. Even though this pond has not shown a significant reduction in its hydroperiod since 1998/99 onward, average minimum and maximum water-table levels have decreased when compared to other ponds.
\end{abstract}

Key words: Pumping, groundwater, hygrophytic vegetation, Matalascañas, sustainability.

\section{RESUMEN}

Cambios hidrológicos de largo plazo durante diecisiete años en lagunas temporales del P. N. de Doñana (SO España)

Se ha realizado un seguimiento de los cambios hidrológicos en 6 lagunas temporales del P. N. Doñana a lo largo de 17 años (desde el 1 octubre de 1989 hasta el 30 septiembre de 2006) mediante la determinación de la profundidad de su nivel freático (en intervalos de 1 a 8 semanas) y la duración de su fase acuática (o hidroperíodo) en cada uno de los ciclos hidrológicos estudiados. La media anual de precipitación fue $559 \mathrm{~mm}$ en el conjunto de los 17 años estudiados que agruparon 6 ciclos muy húmedos, otros 6 moderados y 5 ciclos secos, todos ellos sin una secuencia claramente definida. La duración media del periodo más húmedo comprendió desde octubre hasta marzo (ambos inclusive), mientras que el periodo de estiaje ocupó el resto del año. El nivel freático en las lagunas osciló cada año siguiendo esta alternancia de periodos húmedos y secos, pero esta oscilación fue mínima durante años secos e, incluso, dejó de ocurrir en algunas lagunas. Desde el ciclo 1998/99 en adelante, la duración media del hidroperíodo se ha reducido en 3 meses en la laguna del Charco del Toro y en casi 2 meses en la de El Brezo. En cambio, el resto de lagunas estudiadas, situadas a más de 1 km de Matalascañas, apenas han sufrido una reducción en su hidroperíodo medio. Estos resultados sugieren que la alimentación freática a estas lagunas ha sido probablemente dañada por el efecto de los bombeos de agua subterránea en la población turística de Matalascañas, cuyas estaciones de bombeo se encuentran a menos de $1 \mathrm{~km}$ de las dos lagunas más afectadas (Charco del Toro y Brezo). Es necesario que estas estaciones de bombeo se reubiquen a mayor distancia para impedir que continúen afectando a las 
lagunas del interior de la Reserva Biológica de Doñana y que se desarrolle un plan de manejo específico para esos cuerpos de agua. El seguimiento de los cambios en la vegetación que rodea las lagunas puede servir para detectar, incluso, pequeñas variaciones hidrológicas. La cobertura de Tamarix canariensis ha ido aumentando desde que se estableció en la zona norte de la laguna de Taraje en el estiaje de 1988/89. A pesar de que esta laguna no ha sufrido una reducción apreciable de su hidroperíodo desde 1998/99 en adelante, los niveles freáticos mínimos y máximos han disminuido de media desde esta fecha en comparación con otras lagunas.

Palabras clave: Bombeos, agua subterránea, vegetación higrofítica, Matalascañas, sostenibilidad.

\section{INTRODUCTION}

Human pressure on water resources is particularly severe in the Mediterranean region. As a result, during the past decades a large number of Mediterranean wetlands have been lost, reduced in extent, and degraded (Hollis, 1992). The importance of these aquatic habitats has led to numerous regional and national inventories, restoration programs, and an increasing number of protected wetlands. The Doñana National Park is given the highest degree of environmental protection in Spain: it was designated a Biosphere Reserve in 1980, a Wetland of International Importance by the Ramsar Convention in 1982, a Special Protection Area for birds in 1988, and a World Heritage Site in 1994. Despite this, the intensification of agriculture, urban growth, and the development of tourist resorts on the fringe of this protected land, has long threatened its conservation value, leading to the Doñana National Park being added to the Montreux Record of Ramsar Sites under threat in 1990. In particular, Hollis et al. (1989) pointed out the risks of further extraction of ground water for irrigation along the northeast margin of the park, reduction in stream flow of tributaries entering the marshland on the north, and enlargement of tourist resorts on the coast. An International Expert Commission was eventually set up to report on strategies for the sustainable development of the Doñana region (Castell et al., 1992), and the original plan of land reclamation and irrigation for agriculture, which had been set by the Spanish Government in 1971, was finally reduced by fifty percent.
The proposed addition of 32000 hotel beds at an existing seaside resort adjacent to the park ("Matalascañas") was blocked in 1992, when it was already lodging 75000 summer residents and reaching 200000 people during weekends (Bernard, 1990). A golf course was finally built adjacent to the park in 2000. Nowadays, a single company centralizes groundwater extraction for urban water supply to this resort, wastewater treatment, and the irrigation of the golf course with tertiary treated wastewater.

In contrast to the marshland where the regeneration plan "Doñana 2005" is being implemented, no specific management strategy has yet been developed for hundreds of temporary ponds located on sandy soils within the park, though they form a system of temporary water bodies of remarkable singularity in Europe (Williams et al., 2001). They are fed by rainfall and different aquifer flow systems (Sacks et al., 1992). Damage to pond groundwater supply has been repeatedly questioned since the increase in groundwater extraction (due to the resort enlargement) was modeled by Vela et al. (1991). Oscillations of the groundwater level in deep wells near the pumping area have been observed to follow the tourist season (Serrano and Toja, 1995; Palancar, 1999; Cantos et al., 2005). Ponds closer to the pumping area for urban water supply $(<1 \mathrm{~km})$ experienced a larger drawdown during droughts than those located $2 \mathrm{~km}$ further away (Serrano and Serrano, 1996). Groundwater extraction for urban water supply also contributed to the decline of some hygrophytic vegetation around the ponds (Zunzunegui et al., 1998; Muñoz-Reinoso, 
2001). Despite the mounting ecological evidence of groundwater decline, some uncertainties regarding the extent of the aquifer discontinuities, its vertical heterogeneity (Custodio et al., 1992), and plant transpiration (Lozano, 2004) have released much of the pressure for urgent conservation measurements that were proposed by the International Expert Commission (Castell et al., 1992). Additionally, recent studies have brought into account climate change as a factor explaining the tendency of the Doñana wetlands towards desiccation since the Little Ice Age (Sousa and García-Murillo, 2003).

Monitoring changes in wetland vegetation is, nonetheless, a useful tool for detecting changes to groundwater hydrology, as vegetation is a basic ecosystem feature able to reflect the state of vitality and maturity of the system (Day et al., 2001). The vegetation of Doñana National Park is one of the best examples of systems where plant composition and distribution are driven by water availability resulting from differences in the geomorphology of the landscape (Zunzunegui et al., 1998; Muñoz-Reinoso and García-Novo, 2005). Vegetation around the temporary ponds of Doñana is basically organized in concentric belts, with plants growing around the lower part of the basin largely dependent on the water-table depth, whereas xerophytic vegetation growing on the upper areas depends solely on precipitation. Therefore, pond vegetation behaves as a dynamic system driven by the interannual rainfall fluctuations typical of the Mediterranean climate, which is also affected by other factors such as pond altitude, location and groundwater extraction (Zunzunegui et al., 1998).

In the present study, changes in hydrology were recorded in 6 temporary ponds in the Doñana National Park over 17 years by recording the fluctuation of their shallow water-table and the duration of their wet phase (or hydroperiod) during each hydrological cycle. Additionally, changes in vegetation cover and distribution have been quantified using aerial photographs. In the present study, water-table oscillations were analysed in relation to rainfall variability and groundwater extraction, and it is shown that both pond hydroperiod and plant community changes are useful tools for monitoring hydrological changes in these temporary ponds.

\section{METHODS}

\section{Study area}

The Doñana region lies between $36^{\circ} 48^{\prime}-37^{\circ} 30^{\prime} \mathrm{N}$ and $6^{\circ} 10^{\prime}-6^{\circ} 50^{\prime} \mathrm{W}$. It extends along the coastal plain of the Gulf of Cádiz from the left bank of the estuary of the Guadalquivir River to the estuary of the Tinto River (Huelva), and inland from the coast to the uplands of "Condado de Niebla" (Huelva). This landscape originated in the Quaternary when the estuary of the Guadalquivir River was enlarged and reshaped by the formation of sandy spits after the last postglacial transgression. Deposits on this ancient plain exhibit a rather heterogeneous lithology: the central plain (or marshland) is formed by a silty-clay layer partially covered by aeolian sands, and mixed with deltaic deposits. Consequently, the permeability of these geomorphologic units is very variable: the aeolian sands correspond to an unconfined aquifer with a shallow water-table and several flow systems, while ground water is confined below the silty-clay deposits of the marshland. Both units compose an aquifer system of about $3400 \mathrm{~km}^{2}$ underlined by impermeable marine marls known as the "Almonte-Marismas" aquifer (Llamas, 1990). The depth of the aeolian sand deposits varies from over $100 \mathrm{~m}$ on the coast to barely $10 \mathrm{~m}$ at the northern edge of the Park. Groundwater recharge is produced by rainfall infiltration in the unconfined aquifer at an estimated rate of $200 \mathrm{~mm} \mathrm{yr}^{-1}$ (Vela, 1984).

Several territories within the Doñana region are protected by law from hunting, drainage, forestry plantation, and excessive tourist exploitation: a Biological Reserve of 6700 ha created in 1964, a National Park presently covering 54570 ha, and a surrounding buffer area of over 50000 ha (or Natural Park) created in 1989 (Fig. 1). At the same time, the Doñana region also experiences a very wide variety of anthropogenic pressures as a result of the exploitation of water resources. The area also supports a po- 


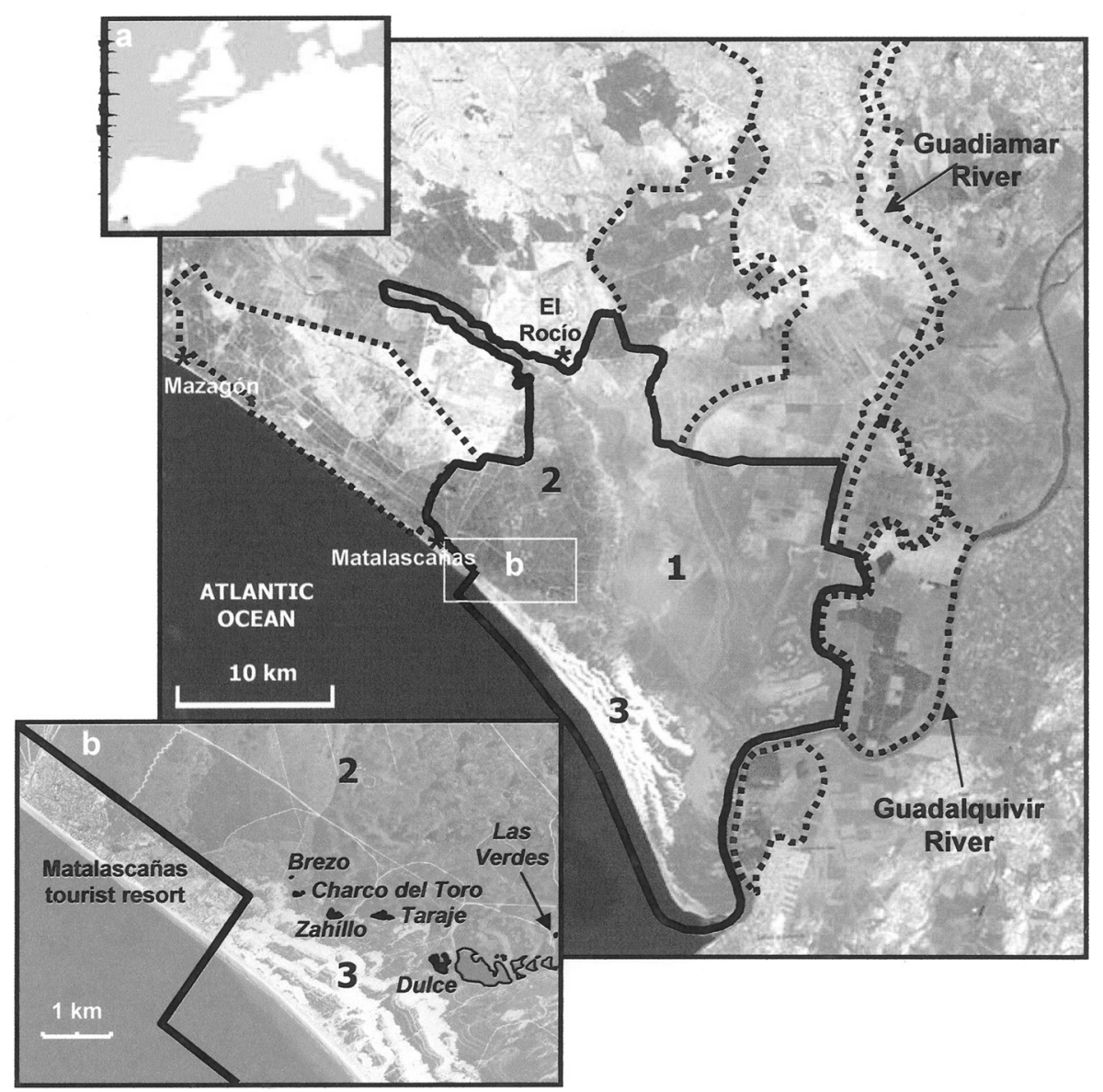

Figure 1. a) Location of the Doñana region and main landscapes within the National Park: marshland (1), stabilized sands (2), and active dunes (3). Boundaries of the National Park (solid line) and the buffer zones (dotted line); b) Location of Matalascañas and of the study ponds (filled in black). a) Localización de la región de Doñana y los principales tipos de paisajes en el Parque Nacional: marisma (1), arenas estabilizadas (2) y dunas móviles (3). Los límites del Parque Nacional se indican con línea continua y los de las zonas de protección en el entorno con línea discontinua; b) ubicación de Matalascañas y de las lagunas estudiadas.

pulation of 180000 inhabitants whose activities are devoted primarily to agriculture, and secondarily to tourism. The tourist resorts of Matalascañas and Mazagón are located on the coast adjacent to the protected areas (Fig. 1). Matalascañas resort attracts over $80 \%$ of the summer tourist demand and supplies water for their activity by extraction from the Almonte-Marismas aquifer. The rate of groundwater extraction was $3 \cdot 10^{6} \mathrm{~m}^{3} \mathrm{yr}^{-1}$ at the beginning of the 1990's (Serrano and Serrano, 1996), with wells ranging from 140 to 172 m deep (Muñoz-Reinoso, 2001).

Doñana has a Mediterranean climate with Atlantic influence, generally classified as dry sub- humid. Rainfall is quite variable, both within the year and between years, with a $580 \mathrm{~mm}$ yearly average. Summers are very dry and hot, while winters are short and mild. Potential evapotranspiration is very high with a yearly average of about 900 mm (Ménanteau, 1982). Although water in Doñana is generally scarce, this region includes an extraordinary variety of aquatic systems. They are broadly classified according to their location (on either aeolian sands or marshland) as their hydrology largely depends on the geomorphology of their basins (Serrano et al., 2006). The aeolian sand mantle is composed of several dune generations originally deposited by 
marine drift in the Holocene. In this undulating landscape, hundreds of small ponds appear when the water-table rises above the topographical surface during heavy rains. These ponds are fed by freshwater (rainfall, runoff, and groundwater discharge) and have no direct connection to the sea except through airborne salt deposition. Ponds overflow towards the marshland during heavy floods. Their groundwater supply is relatively complex due to changes in recharge and topographic boundaries that modify the pond connection to different aquifer flow systems over time (Sacks et al., 1992, Muñoz-Reinoso, 2001). Ponds range widely in size, from rain-fed puddles to shallow lakes, and in flooding duration, from days to decades, but they all have been reported to dry out eventually (Serrano et al., 2006). A total of 568 temporary wetlands on sandy soils have been recorded by the local administration in the whole Doñana region (Junta de Andalucía, 2002), but the number of small ephemeral water bodies is yet to be established. Water $\mathrm{pH}$ in the larger ponds is usually alkaline due to the dominance of $\mathrm{Na}^{+}$over $\mathrm{Ca}^{2+}$. The combination of alkaline waters over siliceous sand basins makes these water bodies unusual in a European context compared to other wetlands in dune formations. Nutrient concentrations and primary production vary widely depending on hydrological conditions, being generally higher in the more permanent ponds.

A system of moving dunes with several fronts runs parallel to the coast-line with a NW-SE direction, reaching a maximum height of $32 \mathrm{~m}$ a.m.s.l., and covering about 10000 ha (Fig. 1). Older dune fronts (maximum height: $40 \mathrm{~m}$ a.m.s.l.) are located inland and were stabilized by vegetation. This vegetation is presently dominated by Mediterranean shrubland, with a species composition that has been long reported to be closely related to the depth of the watertable (González-Bernáldez et al., 1971). Vestiges of a woodland of Juniperus phoenicia with abundant low xerophytic shrubs (Halimium commutatum, Halimium halimifolium, Rosmarinus officinalis, and Cistus libanotis) grow on the upper areas where the water-table usually lies deeper than $3 \mathrm{~m}$. Hygrophytic shrubs grow in wide belts around depressions and ponds, where the water-table rarely lies deeper than $1.5 \mathrm{~m}$ and occasional flooding occurs during very wet periods. This plant community is mainly dominated by Erica scoparia, Erica ciliaris, Calluna vulgaris, Ulex minor, Cistus salvifolius, and isolated individuals of Quercus suber left from the original oak-tree woodland. A mixed community, dominated by $H$. halimifolium and $U$. australis, is located at the transition of this topographic gradient. The most common aquatic emergent macrophytes are Scirpus lacustris, and Eleocharis palustris. Rushes (Juncus effusus and Scirpus holoschoenus) grow on the pond margins over grassland dominated by Agrostis stolonifera, Polypogon maritimus, and Cynodon dactylon, which also invade the pond basin during dry periods. Additionally, the community includes pine trees (Pinus pinea), planted from 1737 onwards, after major changes in management brought about the destruction of the original woodland, although pine trees near the study ponds are the result of recent planting carried out in the 1950's (Granados-Corona et al., 1988).

\section{Data collection}

Rainfall data were obtained from the meteorological station of "Palacio de Doñana" (RBDCSIC). Water-table depth, surface level, and duration of the wet phase (or hydroperiod) were recorded at six temporary ponds: Laguna del Brezo (BRE), Charco del Toro (CTO), Laguna del Zahíllo (ZAH), Laguna del Taraje (TAR), Laguna Dulce (DUL), and Laguna de Las Verdes (LVE). They are located within the Biological Reserve of Doñana, amid the stabilized sands, and close to the border of the mobile dune system (Fig. 1). They range in size and in distance to the tourist resort of Matalascañas: less than $1 \mathrm{~km}$ away (BRE and CTO), $1.4 \mathrm{~km}(\mathrm{ZAH}), 2.2 \mathrm{~km}$ (TAR), $3.6 \mathrm{~km}$ (DUL), and $5.6 \mathrm{~km}$ (LVE).

Hydrological data were collected from October 1989 to September 2005 at 1-8 week intervals throughout 17 hydrological cycles (1989/902005/06). PVC tubes of 4-6 cm diameter were placed in each pond basin at $1.5-3.5 \mathrm{~m}$ depth to record the depth of the water-table. Surface wa- 
ter levels were monitored using 1.5-2.0 m long metal rods firmly fixed at the bottom of each pond basin. Pond altitude was estimated using a topographic map (scale 1:10 000).
Changes in plant cover of Tamarix canariensis were monitored as an evidence of colonization of woody species in pond basins. This species was chosen because older stands can be de-

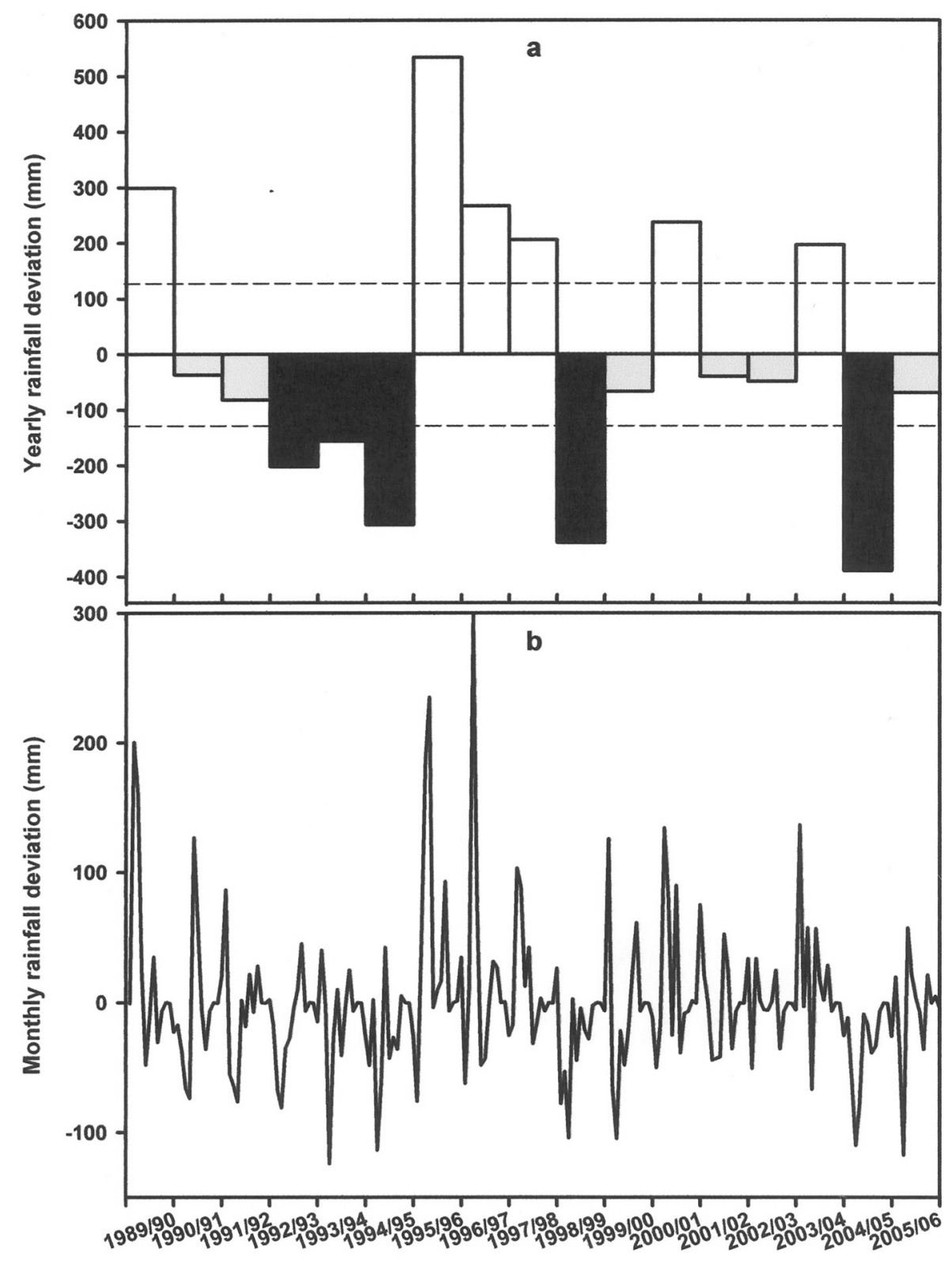

Figure 2. a) Rainfall deviation from the yearly average set at $0 \mathrm{~mm}$, showing wet (no fill), moderate (grey), and dry years (black). Upper and lower confidence limits are marked with dashed lines; b) rainfall deviation from the monthly average set at $0 \mathrm{~mm}$ for each month along the study period. a) Desviación de la precipitación de cada ciclo respecto a la media anual situada en 0 mm, mostrando los ciclos lluviosos ( discontinua; $b$ ) desviación de la precipitación de cada mes respecto a la media mensual situada a $0 \mathrm{~mm}$. 


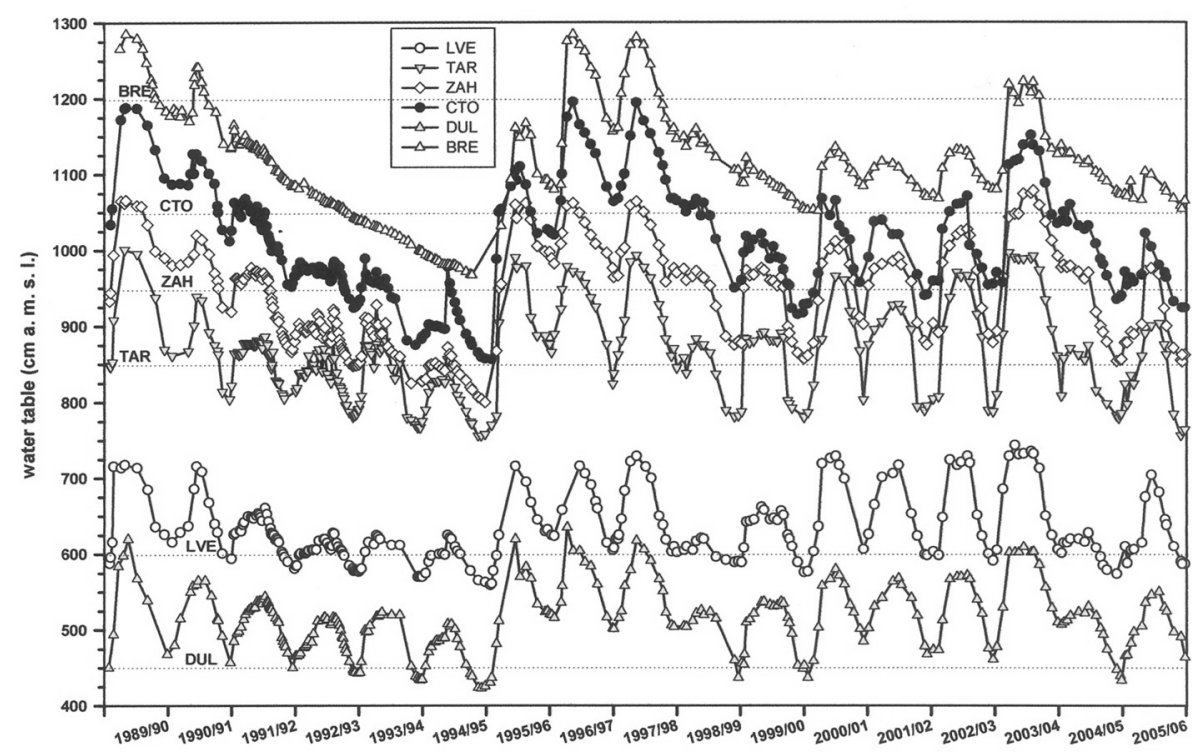

Figure 3. Variation of the water table at the study ponds from 1989/90 until 2005/06. Horizontal dotted lines indicate the altitude of each pond basin (cm a.s.1.). Variación del nivel freáico en las lagunas estudiadas desde el ciclo 1989/90 hasta 2005/06. Las líneas horizontales indican la altitud (cm s.n.m.) del fondo de cada cubeta.

tected and measured by aerial photographs. Plant cover was calculated using a GIS (Geographical Information System) suite (ArcView GIS 3.2) on aerial photographs taken in July 1990 (scale 1:10 000), April 1996 (scale 1:60 000), July 1998 (scale 1:10 000), August 2002 (scale 1:20 000), and June 2004 (scale 1:10 000).

\section{RESULTS}

Yearly rainfall deviated in an irregular pattern from the long-term average $(558.9 \mathrm{~mm})$ over the 17 years of the study (Fig. 2a). Six hydrological cycles were considered as wet years because the rainfall throughout each hydrological cycle was greater than the upper confidence limit of the yearly average $(558.9+117 \mathrm{~mm}$, at $95 \%$ significance). Rainfall remained within the confidence limits on six occasions (moderate years), while it was below the lower confidence limit on five occasions (dry years). The distribution of wet, moderate and dry years did not show any systematic pattern over the study period. The wettest period recorded (1995/96-1997/98) followed a severe drought of three consecutive dry years, while dry, moderate and wet years alternated from $1999 / 98$ to 2005/06.

The deviation of rainfall from the monthly average ranged widely (Fig. 2b). Wet years were generally driven by a large excess of rainfall during a few months from $1^{\text {st }}$ October to $31^{\text {st }}$ March, which can therefore be considered as the average extent of the rainy season. In contrast, the rest of the average year (April-September) accumulated only $108 \mathrm{~mm}$ of rainfall, and can be considered as the dry season. December showed the highest monthly rainfall $(126.4 \mathrm{~mm})$, and July the lowest one $(<0.1 \mathrm{~mm})$.

In general, the shallow water-table fluctuated in the ponds following the alternation of rainy and dry seasons (Fig. 3). This seasonal fluctuation generally occurred within each hydrological cycle though the water level was sometimes lower at the beginning of the rainy season (just before heavy rainfall occurred) than at the end of the corresponding dry season. The maximum seasonal fluctuation occurred in most ponds in 1995/96 when the water-table increased from very low values in November, after a drought period of three successive dry years, to high values after heavy rainfall, ranging from $157 \mathrm{~cm}$ 
Table 1. Hydroperiod measured as number of months per year during which each pond held surface water. Hidroperíodo calculado como el número de meses por año que la laguna mantuvo agua en superficie.

\begin{tabular}{ccccccc}
\hline & BRE & CTO & ZAH & TAR & DUL & LVE \\
\hline $1989 / 90$ & 6.9 & 10.5 & 10.5 & 10.5 & 11.5 & 10.5 \\
$1990 / 91$ & 2.3 & 9.5 & 9.5 & 9.7 & 12 & 10.2 \\
$1991 / 92$ & 0 & 3.5 & 7.1 & 7.5 & 11.7 & 9.8 \\
$1992 / 93$ & 0 & 0 & 0 & 3.6 & 10.7 & 8.1 \\
$1993 / 94$ & 0 & 0 & 0 & 5.7 & 9.5 & 8.1 \\
$1994 / 95$ & 0 & 0 & 0 & 0.4 & 8.0 & 3.9 \\
$1995 / 96$ & 0 & 6.1 & 9.5 & 9.5 & 10.7 & 9.5 \\
$1996 / 97$ & 6.6 & 10.6 & 12 & 11.4 & 12 & 12 \\
$1997 / 98$ & 7.6 & 12 & 12 & 11.1 & 12 & 12 \\
$1998 / 99$ & 0 & 5.8 & 6.7 & 4.7 & 11.6 & 7.4 \\
$1999 / 00$ & 0 & 0 & 7.5 & 8.0 & 11.5 & 9.8 \\
$2000 / 01$ & 0 & 1.8 & 6.8 & 8.6 & 11.3 & 10.5 \\
$2001 / 02$ & 0 & 0 & 8.3 & 8.6 & 12 & 10.7 \\
$2002 / 03$ & 0 & 3.4 & 7.1 & 8.0 & 12 & 9.0 \\
$2003 / 04$ & 6.2 & 8.3 & 11.4 & 11.4 & 12 & 12 \\
$2004 / 05$ & 0 & 0.7 & 5.6 & 5.4 & 10.6 & 7.4 \\
$2005 / 06$ & 0 & 0 & 4.0 & 5.5 & 11.5 & 9.0 \\
\hline
\end{tabular}

at LVE pond to $254 \mathrm{~cm}$ at CTO pond. In contrast, water-table fluctuations were minimal during dry years, ranging from $32 \mathrm{~cm}$ at LVE pond to $81 \mathrm{~cm}$ at TAR pond, and even failed to occur at BRE pond where the water-table followed a decreasing trend over several years. This lack of fluctuation was also observed at CTO and ZAH ponds though only during the dry year of 2004/05 (Fig. 3). The shallow water-table below some study ponds occasionally showed a rapid rise of a few cm from August to September, coincident with the end of the main tourist season. For example, the water-table at TAR pond rose by $6 \mathrm{~cm}$ in two weeks in the absence of any rainfall in September 2005.

When the water-table rose above the bottom of the pond basin, ponds stored water on their surface. The duration of this aquatic phase, or hydroperiod, was different at each pond (Table 1). DUL pond exhibited the longest hydroperiod of the studied ponds: it stored water each year, but dried out eleven times at the end of the dry season. BRE pond, in contrast, had the shortest hydroperiod, storing some water in five out of 17 years, and drying out every dry season of flooding years. The rest of the ponds occupied an intermediate position in terms of hydroperiod and drying frequency. The hydroperiod at each pond was positively correlated with rainfall, but these
Table 2. Linear correlation coefficients between hydroperiod and total rainfall collected in the present year (one year), and that from both the present and the previous year (two years). $* p<0.05 ; * * p<0.01$. Coeficientes de correlación lineal entre hidroperíodo y precipitación recogida en ese mismo ciclo o en ambos ciclos (presente y anterior).

\begin{tabular}{llc}
\hline & one year & two years \\
\hline BRE & $0.540^{*}$ & $0.712^{* *}$ \\
CTO & $0.592^{*}$ & $0.806^{* *}$ \\
ZAH & $0.672^{* *}$ & $0.819^{* *}$ \\
TAR & $0.786^{* *}$ & $0.811^{* *}$ \\
DUL & 0.376 & $0.555^{*}$ \\
LVE & $0.708^{* *}$ & $0.746^{* *}$ \\
\hline
\end{tabular}

correlations were higher and more significant for all ponds when the rainfall collected during the previous year was summed up with that collected in the present year (Table 2). This result highlighted the importance of the previous conditions on the hydrology of these ponds at a given time. The hydroperiod of the intermediate ponds (LVE, TAR, ZAH and CTO) followed a similar pattern according to rainfall variation from 1989/90 till 1997/98, but the hydroperiod of CTO pond failed to co-vary with those of the other ponds from 1998/99 onwards as CTO did not store water on its surface during the moderate years of 1999/00, 2001/02 and 2005/06 (Fig. 4). Consequently, its average hydroperiod decreased by 3 months from $1998 / 99$ onwards compared to the previous years (1989/90-1997/98) and by 1.8 months in BRE pond. In contrast, the average hydroperiod of the rest of ponds hardly decreased.

It was expected that these changes in hydroperiod pattern would have produced significant changes in the plant communities. One of the most conspicuous changes in vegetation has been the increase of Tamarix canariensis plant cover in TAR pond (Table 3 ). This woody plant

Table 3. Cover $\left(\mathrm{m}^{2}\right)$ of Tamarix canariensis in Taraje pond, throughout the study period as quantified through aerial photographs. Cobertura $\left(\mathrm{m}^{2}\right)$ de Tamarix canariensis en la laguna de Taraje a lo largo del periodo de estudio determinada mediante fotografía aérea.

\begin{tabular}{cc}
\hline Date & Plant cover \\
\hline July 1990 & 3620 \\
April 1996 & 5400 \\
July 1998 & 6780 \\
August 2002 & 8160 \\
June 2004 & 9150 \\
\hline
\end{tabular}




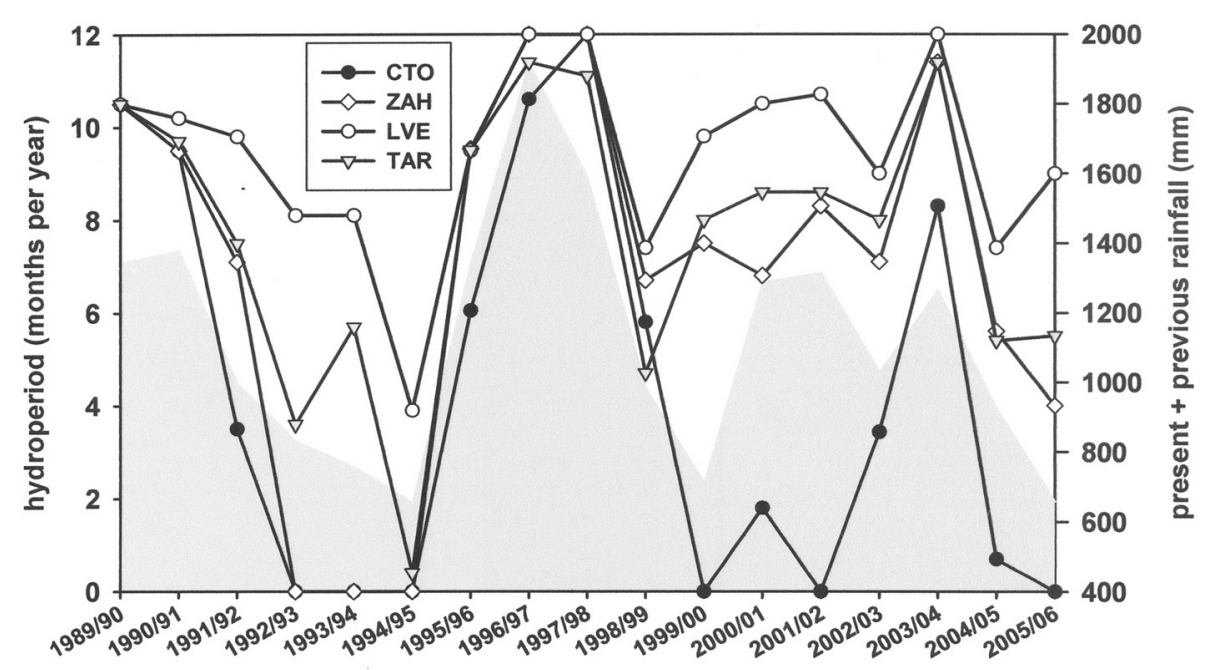

Figure 4. Variation of the hydroperiod of several ponds from 1989/90 till 2005/06. The shaded area represents the sum of rainfall collected between the present and the previous year. Variación del hidroperíodo en algunas lagunas estudiadas. La zona sombreada indica la precipitación conjunta del presente ciclo y del anterior.

species was already established on the northern side of the pond basin in September 1989, just before this present hydrological record started. Despite that the hydroperiod of TAR pond has not been significantly reduced throughout the present record, minimum and maximum water-table levels were lower, on average, since 1998/99 onward compared to previous cycles. LVE pond, in contrast, did not show any reduction in water-table levels, and only maximum water-table levels decreased in DUL pond.

\section{DISCUSSION}

The recovery of the shallow water-table during wet years showed that ground water was effectively feeding the study ponds as long as a large surplus of rainfall maintained groundwater recharge. Water-tables fluctuated seasonally at LVE, DUL and TAR ponds even during dry and moderate years, but followed a decreasing trend at BRE pond. The water-table at CTO pond fluctuated seasonally, but this fluctuation was very small in 1999/00 and 2004/05 as the water-table dropped $0.9 \mathrm{~m}$ from April to August 2000, and $1 \mathrm{~m}$ from December 2004 to August 2005. The lack of water-table fluctuation at BRE and CTO ponds during dry years indicated damage to their groundwater supply in recent decades (Serrano and Serrano, 1996). The causes of groundwater damage to these ponds have been reported to be multiple (Serrano and Serrano, 1996; MuñozReinoso, 2001). In the first place, the aquifer is not vertically uniform so hydraulic permeability is expected to be different in the shallow watertable $(<2 \mathrm{~m})$ compared to the unconfined top layer (up to $90 \mathrm{~m}$ deep in the study area) and the deeper semi-confined layer below it (Lozano, 2004). At a regional scale, ground water flows NW-SE towards the sea and the marshland, and discharges in depressions where the ponds are located at different altitudes, BRE pond being $7 \mathrm{~m}$ higher than DUL pond. At a local scale, the shallow water-table below the mobile dunes might contribute differently to the water supply of the study ponds according to their proximity to the dune front. Additionally, higher ponds can be expected to have a shorter wet phase than lower ponds because invasion by upland vegetation is enhanced by a longer dry season (Zunzunegui et al., 1998). Furthermore, it is likely that the denser the plant cover growing on the dry basin, the higher the groundwater loss by transpiration. On the other hand, the distance of these ponds to the water extraction area increases 
in a NW-SE direction, with CTO pond being $4.5 \mathrm{~km}$ closer than LVE pond to the Matalascañas groundwater pumping area.

Despite the multiple factors involved in pond groundwater supply, Vela et al. (1991) anticipated the drying out of ponds near the tourist resort of Matalascañas if groundwater extraction for urban supply increased to a rate of $4 \cdot 10^{6} \mathrm{~m}^{3} \mathrm{yr}^{-1}$. Their groundwater flow model was modular and bi-dimensional; they assigned an average hydraulic permeability of $0.86 \mathrm{~m} \mathrm{~d}^{-1}$, and assumed that the aquifer was entirely unconfined. Their model predicted a groundwater decline of over $2 \mathrm{~m}$ at BRE pond after 10 years of simulated water extraction. More recently, a numerical simulation model predicted an annual groundwater decline of about $0.37 \mathrm{~m}$ at CTO pond for every $10^{6} \mathrm{~m}^{3}$ of increase in groundwater extraction at Matalascañas, which may eventually lead to the drying out of this pond (Lozano, 2004). In this model, hydraulic permeability was varied at each piezometer (0.11-2.5 $\left.\mathrm{m} \mathrm{d}^{-1}\right)$ according to the proportion of coarse sand and fine sediment at each location.

In 2001/02, ten years after the publication of the simulation by Vela et al. (1991), the water-table had declined by $1 \mathrm{~m}$ at BRE pond and by $0.8 \mathrm{~m}$ at CTO pond whereas ponds more than $1 \mathrm{~km}$ away from the tourist resort showed a very small decline $(<0.25 \mathrm{~m})$ or none at all (such as LVE and DUL ponds). Contrary to the simulation by Vela et al. (1991), the water-table at BRE pond recovered and fluctuated seasonally during wet cycles though it did decline during dry and moderate years.

The annual rate of groundwater extraction for urban water supply at Matalascañas tourist resort was already $3.2 \cdot 10^{6} \mathrm{~m}^{3}$ in 1990 (Serrano and Serrano, 1996). No water restrictions of any kind were imposed on this tourist resort during the severe drought of 1993-95 despite that water for both irrigation and urban supply were drastically cut down in nearby areas where water was being provided by reservoirs and rivers. Monitoring of a deep piezometer, located at about $0.9 \mathrm{~km}$ from the Matalascañas pumping stations, proved the influence of groundwater extraction on the Doñana Biological Reserve as the water-table recovered every September at the end of the tourist season, even in the absence of rainfall, resulting in ground water attaining levels typical of late spring (Serrano \& Toja, 1995; Serrano \& Serrano, 1996). It has been argued, however, that this piezometer is not able to give the exact position of the water-table if the aquifer is semi-confined because it has several well screens placed at different depths. For this reason, two surveillance wells were installed on the side of this deep piezometer in 2001, with a well screen placed at $25 \mathrm{~m}$ depth in one, and at $45 \mathrm{~m}$ depth in the other. These new wells also registered an increase of the water-table in the absence of rainfall of 11 and $38 \mathrm{~cm}$, respectively, in September 2001, resulting in the recovery of water-table levels achieved in June 2001 (unpublished data). A decline in plant transpiration between August and early September was also claimed to have produced this water-table increase though plant transpiration in the wet-slack formation of the sand dunes has been estimated to produce a daily oscillation of only $1 \mathrm{~cm}$, and to reach its maximum in May, coincident with the spring vegetative growth (Olías et al., 1996).

The significance of the amount of rainfall collected in the previous year during the hydroperiod of the Doñana ponds is an important issue for the protection of temporary systems because it shows that the effect of one dry year also extends to the following year. A recent numerical model proved to be very sensitive to the original conditions of either rainy or dry seasons, as well as to the magnitude of plant transpiration (Lozano, 2004). An increase in plant cover will eventually enhance transpiration if plant growth persists. This is particularly the case for severe dry periods (or droughts) when the lack of surface water cannot prevent the establishment of plant seedlings on the pond basins. During floods, most of these changes are reversed and only flooding-dependent species are expected to survive. The growth of Tamarix $\mathrm{ca}$ nariensis on the northern side of TAR pond did not stop during the following floods. Furthermore, plant cover has been increasing over time. At present, the plant stands that started to grow in September 1989 are higher than the maximum water depth that this pond can attain (as 
the pond basin drains water through several outlets) and thus, this change is not a mere vegetation fluctuation but a directional change because it can not be naturally reversed. The extremely dry cycle of 2004/05 promoted a further recruitment of this plant species on the pond basin that has, so far, survived the subsequent rainy seasons. The growth rate of xerophytic species invading the dry pond basin has been reported to be extremely fast in these ponds: the xerophytic shrub $H$. halimifolium is able to reach a height of $50 \mathrm{~cm}$ within two years when it growths on a dry pond basin (Zunzunegui et al., 1998). Initial changes in pond hydrology and vegetation in BRE pond may be dated to 1973-1974 when pine trees invaded the pond basin following a decrease in hygrophytic shrub cover around this pond (MuñozReinoso, 2001). The cover of S. lacustris, which is a macrophyte with a high dependence on flooding, was reduced by nearly half between 1990 and 2005 in CTO pond probably due to a reduction in hydroperiod (Serrano \& Zunzunegui, in press). The importance of vegetation changes in wetlands located on aeolian sands was studied in the Douro Basin, where the impact of groundwater extraction produced a gradual disappearance of sloughs until changes became irreversible, and did not recover even during extremely wet years (González-Bernáldez et al., 1993).

The fluctuation of the water-table at the Doñana temporary ponds undoubtedly reflects the interaction of many factors, such as pond altitude, basin morphometry, plant transpiration, local hydraulic permeability, distance to the pumping area, etc. Some of these variables are difficult to quantify in detail, but this study detected changes in pattern over a 17-year record of watertable levels and hydroperiod. The water-table of two ponds closer to the tourist resort $(<1 \mathrm{~km})$ failed to follow the same pattern as the rest of the ponds, particularly during dry years. A further increment in plant cover invading their basins will increase plant transpiration and so reduce groundwater discharge. A proper water management plan for this tourist resort is required if the Doñana ponds are to be protected, particularly during drought when these aquatic systems are more sensitive to larger vegetation changes.
The pumping area of the Matalascañas tourist resort should be relocated in order to prevent further damage to the Doñana temporary ponds. This conclusion confirms what was already proposed in the sustainable development strategy for the Doñana region published by Castell et al. (1992) nearly 15 years ago, which suggested moving the pumping area one or two km further to the west. We also recommend reducing the present groundwater extraction rate during dry periods. More specifically, water-saving measures should be implemented in the tourist resort area during the summer months when the sum of rainfall collected during the previous hydrological year and the present year (up to $1^{\text {st }}$ June) is below the lower confidence limit of the historical average (ca. $921 \mathrm{~mm}$ ). This limit hardly changes $(935 \mathrm{~mm})$ taken into account the whole precipitation record available at the meteorological station of Palacio de Doñana from 1979/80 onwards. This rainfall limit has failed to be exceeded on seven occasions according to this study: 1991/92, 1992/93, 1993/94, 1994/95, 1999/00, 2004/05 and 2005/06. Once restrictions are in place, the recovery of vegetation and the hydroperiod should be carefully monitored in case plant transpiration still diminishes groundwater discharge into some ponds. In that case, removal of woody plant species established in the pond basin would be required.

\section{ACKNOWLEDGEMENTS}

We are most grateful to the Biological Station of Doñana for their support. This study was partially funded by Confederación Hidrográfica del Guadalquivir (project Donagua 1989-92), the Spanish Ministry of Science (CAICYT AMB-1054, 1995-98), and Fundación Areces (2002-2004).

\section{REFERENCES}

BERNARD, C. 1990. Agriculture et tourisme sur la côte Atlantique Andalouse: la "Costa de la Luz" de Huelva. Mélanges de la Casa de Velázquez, XXVI: 151-173. 
CANTOS, R., M. PALANCAR y R. E. VEGA. 2005. Análisis del estado cuantitativo de las aguas subterráneas en la Unidad Hidrogeológica AlmonteMarismas. In: VI Simposio del Agua en Andalucía. J. López-Geta, J. C. Rubio, M. Martín (eds.): $397-$ 405. IGME, Madrid. J. López-Geta, J. C. Rubio, M. Martín (eds.): 397-405. VI Simposio del Agua en Andalucía. IGME.

CASTELL, M., J. CRUZ, E. CUSTODIO, F. GARCÍA-NOVO, J. P. GAUDEMAR, J. L. GONZÁLEZ-VALLVÉ, V. GRANADOS, A. MAGRANER, C. ROMÁN, M. SMART y E. VAN DER MAAREL. 1992. Dictamen sobre estrategias para el desarrollo socioeconómico sostenible del Entorno de Doñana. Junta de Andalucía, Sevilla, Spain. 125 pp.

CUSTODIO, E., J. DOLZ, J. GUIMERÁ, M. MANZANO, R. PONCELA, J. SAMPER, M. SÁNCHEZ y E. VELASCO. 1992. Aportaciones al conocimiento hidrogeológico de los acuíferos del Parque Nacional de Doñana y su entorno. Hidrología y Recursos Hidraúlicos, XVI: 425-439.

DAY, F. P., E. R. CRAWFORD \& J. J. DILUSTRO. 2001. Aboveground plant biomass change along a coastal barrier island dune chronosequence over a six-year period. Journal of the Torrey Botanical Society, 128: 197-207.

GONZÁLEZ-BERNÁLDEZ, F., F. GARCÍA-NOVO et L. RAMÍREZ-DÍAZ. 1971. Analyse factorielle de la végétation des dunes de la Reserve Biologique de Doñana (Espagne). Colloques Phytosociologiques. I Dunes. París, France: 185-200.

GONZÁLEZ-BERNÁLDEZ, F., J. M. REY-BENAYAS \& A. MARTÍNEZ. 1993. Ecological impact of groundwater extraction on wetlands (Douro Basin, Spain). J. Hydrol., 141: 219-238.

GRANADOS-CORONA, M., A. MARTÍN-VICENTE \& F. GARCÍA-NOVO. 1988. Long-term vegetation changes on the stabilized dunes of Doñana National Park (SW Spain). Vegetatio, 75: 73-80.

HOLLIS, G. E., J. MERCER \& P. HEURTEAUX. 1989. The implications of groundwater extraction for the longterm future of the Doñana $\mathrm{Na}$ tional Park. WWF/IUCN/ADENA Mission to the Doñana National Park, $18^{\text {th }}-22^{\text {nd }}$ November 1988. $60 \mathrm{pp}$.

HOLLIS, G. E. 1992. The causes of wetland loss and degradation in the Mediterranean. In: Managing Mediterranean wetlands and their birds. C. M.
Finlayson, G. E. Hollis, T. J. Davis (eds.): 8390. IWRB Special Publication No. 20, Slimbridge, UK.

JUNTA DE ANDALUCÍA. 2002. Plan andaluz de humedales. Consejería de Medio Ambiente, Sevilla, Spain. 253 pp.

LLAMAS, R. 1990. Geomorphology of the eolian sands of the Doñana National Park (Spain). Catena Supplement, 18: 145-154.

LOZANO, E. 2004. Las aguas subterráneas en Los Cotos de Doñana y su influencia en las lagunas. $\mathrm{PhD}$ Thesis, Universidad Politécnica de Barcelona, Barcelona, Spain. 414 pp.

MÉNANTEAU, L. 1982. Les Marismes du Guadalquivir, exemple de transformation d'un paysage alluvial au curs du Quaternaire recent. $\mathrm{PhD}$ Thesis, Université Paris-Sorbonne, Paris, France. 252 pp.

MUÑOZ-REINOSO, J. C. 2001. Vegetation changes and groundwater abstraction in SW Doñana, Spain. J. Hydrol., 242: 197-209.

MUÑOZ-REINOSO, J. C. \& F. GARCÍA-NOVO. 2005. Multiscale control of vegetation patterns: the case of Doñana (SW Spain). Landscape Ecology, 20: 51-61.

OLÍAS, M., J. CRUZ-SANJULIÁN \& J. BENAVENTE. 1996. Estimation of transpiration from water-table oscillations in sand dunes (Corral Largo, Doñana National Park, Spain). In: Wetlands: a multiapproach perspective. J. López-Geta, J. C. Rubio \& M. Martín (eds.): 103-110. University of Granada, Granada, Spain.

PALANCAR, M. 1999. Aguas subterráneas y humedales. I Reunión Internacional de expertos sobre la regeneración hídrica de Doñana. Doñana 2005. Ministerio de Medio Ambiente, Madrid, Spain: 153-156.

SACKS, L. A., J. S. HERMAN, L. F. KONIKOW \& A. L. VELA. 1992. Seasonal dynamics of groundwater-lake interactions at Doñana National National Park, Spain. J. Hydrol., 136: 123-154.

SERRANO, L. \& J. TOJA. 1995. Limnological description of four temporary ponds in the Doñana National Park (SW Spain). Arch. Hydrobiol., 133: 497-516.

SERRANO, L. \& L. SERRANO. 1996. Influence of groundwater exploitation for urban water supply on temporary ponds from the Doñana National Park (SW Spain). J. Environ. Manage., 46: 229238.

SERRANO, L., M. REINA, G. MARTÍN, I. REYES, A. ARECHEDERRA, D. LEÓN \& J. TOJA. 2006. 
The aquatic systems of Doñana (SW Spain): watersheds and frontiers. Limnetica, 25: 11-32.

SERRANO, L. \& M. ZUNZUNEGUI. En prensa. The relevance of preserving temporary ponds during drought: hydrological and vegetation changes over a sixteen-year period in the Doñana National Park (SW Spain). Aquat. Conserv. Mar. Freshw. Ecosyst.

SOUSA, A. \& P. GARCÍA-MURILLO. 2003. Changes in the wetlands of Andalusia (Doñana Natural Park, SW Spain) at the end of the Little Ice Age. Climatic Change, 58: 193-217.

VELA, A., J. RODRÍGUEZ y J. L. TENAJAS. 1991. Análisis de los efectos de la explotación del acuífero costero en las proximidades del Parque Nacional de Doñana (Huelva). XXIII Proceedings of the International Association of Hydrogeology:
Aquifer overexploitation, Puerto de La Cruz, Islas Canarias, España: 179-182.

VELA, A. 1984. Estudio preliminar de la hidrogeología e hidrogeoquímica del sistema de dunas móviles y flecha litoral del Parque Nacional de Doñana. Master thesis, Universidad Complutense de Madrid, Madrid, Spain. 221 pp.

WILLIAMS, P., J. BIGGS, G. FOX, N. PASCALE \& M. WHITFIELD. 2001. History, origins and importance of temporary ponds. Freshwater Forum, 17: 7-15.

ZUNZUNEGUI, M., M. C. DÍAZ-BARRADAS \& F. GARCÍA-NOVO. 1998. Vegetation fluctuation in Mediterranean dune ponds in relation to rainfall variation and water extraction. Applied Vegetation Science, 1: 151-160. 
